\title{
Free amino acids and bioactive profile of Pastırma during its processing
}

\section{Ebru Deniz ${ }^{1}$, Leticia Mora ${ }^{2}$, M-Concepción Aristoy ${ }^{2}$, Kezban Candoğan ${ }^{1}$ and Fidel}

\section{Toldrá ${ }^{2,3}$}

${ }^{1}$ Ankara University, Faculty of Engineering, Department of Food Engineering, Ankara, Turkey and ${ }^{2}$ Instituto de Agroquímica y Tecnología de Alimentos (CSIC), Avenue Agustín Escardino 7, 46980 Paterna (Valencia), Spain

${ }^{3}$ Author for correspondence

\begin{abstract}
This study is focused on the characterization of the proteolysis occurred during the processing of Pastırma, a traditional Turkish dry-cured meat product, which is responsible for its final characteristics. Thus, the evaluation of naturally generated free amino acids and peptides present at $0,2,5,10$, and 21 days of processing and the bioactivity of peptide fractions have been approached. Peptides were examined by MALDI-TOF and results showed differences in the amount of generated peptides at different times of processing, and a total of 29 peptides were newly generated at Day 21 in comparison with Day 2 during processing. The water soluble fraction of Pastırma at the end of the curing period (Day 21) was also analyzed by size-exclusion chromatography and some of the collected fractions demonstrated strong ACE-inhibitory and antioxidant activities. In fact, Pastırma showed an ACE inhibitory activity higher than 86\% from 220 to $270 \mathrm{~mL}$ corresponding to molecular masses between 900 and $1500 \mathrm{Da}$, and also a DPPH radical-scavenging activity above $60 \%$ at 250 to $300 \mathrm{~mL}$ corresponding to molecular masses between 700 and 2000 Da. Thus, Pastırma represents a good source of natural ACE-
\end{abstract}


inhibitory and antioxidant peptides which might be due to the proteolysis occurred by endogenous enzymes and the contribution of the çemen paste used in production

Key words: Pastırma, Proteolysis, Free amino acids, Bioactive peptides, Antioxidant activity, Antihypertensive effect

\section{Highlights}

- An intense proteolysis occurred during Pastırma processing.

- Individual and total free amino acids content increased during processing of Pastirma.

- MALDI-TOF spectra confirmed naturally generated peptides of a wide range of molecular masses.

- Pastırma bioactive peptides had strong antihypertensive and antioxidant activity.

- Çemen paste contributed to the high bioactivity of Pastırma. 


\section{Introduction}

Pastırma is a Turkish traditional dry-cured meat product which is produced using whole muscles obtained from certain parts of slaughtered cattle. Dry-curing (salting), drying, pressing, coating with çemen paste, and final drying with çemen (ageing) are the traditional processing steps in the manufacturing of Pastırma (Öztan, 2005). Pastırma production is a fast process that generally takes 3-4 weeks (Gök, Obuz, \& Akkaya, 2012) where salt diffusion occurs rapidly. In this sense, the time required to reach homogenous salt concentration in the muscle is similar to other dry-cured products such as dry-cured loin probably due to its similarity in size and muscle composition (Sentandreu \& Toldrá, 2001).

Proteolysis is the main process contributing to the unique characteristics of dry-cured meat products (Aristoy \& Toldrá, 1995; Lametsch et al., 2003; Toldrá, 1998; Toldrá \& Flores, 1998), resulting in the accumulation of large amounts of free amino acids (Sforza et al., 2001; Toldrá, Aristoy, \& Flores, 2000) and peptides of different sizes (mainly small peptides) (Mora, Sentandreu, Fraser, Toldrá, \&Bramley, 2009; Mora et al., 2009; Sentandreu et al., 2003). Endogenous muscle enzymes (Toldrá, 1998; Toldrá \& Flores, 1998; Toldrá, Rico, \& Flores, 1993) are mainly responsible for degradation of the proteins (Toldrá, Cerveró, \& Part, 1993). These biochemical changes as well as the addition of çemen paste give rise to the characteristic taste and flavor of Pastırma.

Some studies have described proteolysis in Pastırma, mainly with conventional methods such as the determination of non-protein nitrogen content, SDS-PAGE, etc., (Ahhmed, 2013; Ahhmed et al., 2013; Ahhmed et al., 2014; Kızılkaya, 2012; Soyer, Uğuz, \& Dalmış, 2011; Uğuz, 2007), while Ceylan and Aksu (2011) analyzed individual free amino acids in Pastırma sold in local markets. Nevertheless, no studies have been published dealing with the 
characterization of generated peptides during Pastırma processing and the study of their bioactivity.

Bioactive peptides have various health promoting effects such as antioxidant and prebiotic properties, opiate, antithrombotic or antimicrobial activity, immunomodulatory, mineralbinding ability or cholesterol and blood pressure lowering (ACE-inhibitory) effects (Chernukha, Fedulova, \& Kotenkova, 2015; Korhonen \& Pihlanto, 2003; Walther \& Sieber, 2011). The bioactivity of peptides is based on their amino acid composition (peptides that usually contain between 3 and 20 amino acid residues), sequence, size, configuration and molecular mass, which are also affected by processing conditions (Korhonen \& Pihlanto, 2003; Matsui \& Matsumoto, 2006; Pihlanto-Leppälä, 2000). Some recent studies have shown Spanish dry-cured ham as a natural source of peptides with antioxidant activity and antihypertensive effect (Escudero, Aristoy, Nishimura, Arihara \& Toldrá, 2012; Escudero, Toldrá, Sentandreu, Nishimura \& Arihara, 2012; Mora, Escudero, Fraser, Aristoy \& Toldrá, 2014). To the best of our knowledge no study has been published on the naturally generated bioactive peptides in Pastırma and the molecular weight distribution of these peptides. In this context, one of the objectives of the present work was to monitor the profiles of free amino acids (FAAs) and peptides generated in the traditional Turkish meat product Pastırma to better understand the possible relation of the specific components with the production of bioactive peptides during its processing. What is more, the present study also involves the bioactivity assessment of generated peptides by analysing for the first time ACE-inhibitory and antioxidant activity.

\section{Materials and Methods}

\subsection{Pastırma production and sample preparation}


Pastırma production was conducted using methods reported by Aksu (1999), Soyer et al. (2011) and Yagli and Ertas (1998), with some modifications. Beef Longissimus dorsi muscles (n=6), after trimming visible connective tissue and fat, were used in the production.

Processing steps were presented in Figure 1 . Çemen paste was prepared by mixing $50 \%$ çemen flour, also known as fenugreek flour (Trigonella foenum graceum), 35\% crushed fresh garlic and $15 \%$ paprika powder (w:w), then, by dissolving this dry çemen mixture in water (1:2, w:v). Samples were analyzed at days 2 (curing), 5 (first pressing), 10 (third drying) and 21 (end product) of Pastırma processing.

\subsection{Characterization of Pastırma}

\subsubsection{Moisture content}

The moisture content (\%) of Pastırma samples was measured at each sampling day using electronic moisture analyser HB-43 halogen from Mettler Toledo (Barcelona, Spain) at $175^{\circ} \mathrm{C}$ by triplicate.

\subsubsection{Salt content estimated from Na determination}

Salt content was estimated from sodium $\left(\mathrm{Na}^{+}\right)$concentration. Samples from inside, surface and whole Pastırma at each sampling point were measured in triplicate according to Armenteros, Aristoy, Barat and Toldrá (2012). A Metrohm 838 Advanced Sample Processor (Metrohm ${ }^{\circledR}$ Ltd., Herisau Switzerland) in an Advanced Compact IC 861 ion chromatograph (IC) equipped with a conductivity detector and a Metrosep C3 $(250 \times 0.4 \mathrm{~mm})$ column (Metrohm ${ }^{\circledR}$ Ltd.). Software IC Net 2.3 (Metrohm ${ }^{\circledR}$ Ltd.) was used to monitor separation. Samples were taken with a cylindrical borer transversally (3 $\mathrm{cm}$ of diameter). After taking this cylindrical sample, çemen layer was manually removed. The central part, consisting of approximately one third of the 
whole length of cylindrical sample, was taken out and used as the inside sample. The remaining two thirds were used as surface part.

\subsubsection{Analysis of free amino acids and dipeptide contents}

Proteins were extracted from the whole Pastırma samples at each sampling step after manually removal of çemen paste and were deproteinized (Aristoy \& Toldrá, 1991). The same procedure was also applied to the çemen paste. N-Leucine $(1 \mathrm{mM})$ was used as internal standard. Amino acids were analyzed after derivatization with phenyl isothiocyanate (Bidlingmeyer, Cohen, Tarvin, \& Frost, 1986). Phenyl thiocarbamyl amino acid derivatives were separated by reverse phase in a 1200 Agilent HPLC (Agilent Technologies, Santa Clara, CA, USA) using a Pico Tag column (300x3.9 cm) (Waters, Ireland). The mobile phases and separation conditions described in Flores, Aristoy, Spanier, and Toldrá, (1997) were used. Detection was at $254 \mathrm{~nm}$, and amino acids were identified by their retention times compared to standards.

\subsection{Extraction and deproteinization}

Five g sample of each part was homogenized with $20 \mathrm{~mL}$ of $0.01 \mathrm{~N} \mathrm{HCl}$ in a Stomacher (IUL Instrument, Barcelona, Spain) for $8 \mathrm{~min}$ at $4^{\circ} \mathrm{C}$. The homogenate was further centrifuged at $12000 \mathrm{xg}$ for $20 \mathrm{~min}$ at $4^{\circ} \mathrm{C}$. The supernatant was filtered through glass wool, deproteinized by the addition of 3 volumes of ethanol, kept at $4^{\circ} \mathrm{C}$ overnight, and centrifuged at $12000 \mathrm{x}$ g (20 $\min$ at $4^{\circ} \mathrm{C}$ ). Ethanol in the supernatant was evaporated in a rotary evaporator and samples were further lyophilized for water evaporation.

\subsection{Peptide-mass mapping by MALDI-TOF MS}

Whole samples at each sampling step, and inside and surface parts of final Pastırma samples after removal of their çemen layer were analyzed by MALDI-TOF-MS to determine the

molecular mass of peptides generated at different times of processing. Dried samples were 
resuspended in $50 \mu \mathrm{L}$ acetonitrile: $\mathrm{H}_{2} \mathrm{O}(2: 98, \mathrm{v} / \mathrm{v})$ with $0.1 \%(\mathrm{v} / \mathrm{v})$ of trifluoroacetic acid (TFA) and $1 \mu \mathrm{L}$ of each sample was directly spotted onto the MALDI target plate and then allowed to air dry. A 5800 MALDI-TOF instrument (AB Sciex, MA, USA), which was used in a range from 800 to 2000 Da as previously indicated in Lassoued et al. (2015). The analysis of data was done using mMass software (http://www.mmass.org/).

\subsection{Size-exclusion chromatography (Molecular mass fractionation)}

Molecular mass fractionation was performed in the final Pastırma product after removal of the çemen layer in the samples from the whole, inside and surface parts. Five millilitres of each deproteinized extract were subjected to size-exclusion chromatography (SEC) using a Sephadex G25 gel filtration column (2.5x65 cm, Amersham Biosciences, Uppsala, Sweden), which was previously equilibrated by passing 3 column volumes of $0.01 \mathrm{~N} \mathrm{HCl}$, in order to fractionate the peptides according to their size (Escudero, Mora, \& Toldrá, 2014). Fractions were then monitored by ultraviolet (UV) absorption at 214, 254 and $280 \mathrm{~nm}$ (Agilent $8453 \mathrm{UV}$ spectrophotometer, Agilent Technologies, Palo Alto, CA, USA) to obtain the chromatograms. Fractions corresponding to elution volumes from $100 \mathrm{~mL}$ (20 ${ }^{\text {th }}$ fraction) to $600 \mathrm{~mL}\left(120^{\text {th }}\right.$ fraction) were lyophilized. The remaining residue was dissolved in $1 \mathrm{~mL}$ of bi-distilled water, and then consecutive fractions (in pairs) were pooled (e.g. $19^{\text {th }}$ and $20^{\text {th }}$ fractions, $21^{\text {th }}$ and $22^{\text {th }}$ fractions), and stored at $-20^{\circ} \mathrm{C}$ until being used for ACE inhibitory activity and antioxidant activity assays.

\subsection{Assay of angiotensin I-converting enzyme inhibitory activity}

The angiotensin I-converting enzyme (ACE) inhibitory activity of the peptide fractions obtained after G-25 separation in the extracts from inside, surface and whole Pastırma parts were measured in triplicate according to the method developed by Sentandreu and Toldrá (2006) with minor changes. In brief, $50 \mu \mathrm{L}$ of each pooled fraction was mixed with $50 \mu \mathrm{L}$ of 
$150 \mathrm{mM}$ Tris-base buffer (pH 8.3) containing $7.5 \mathrm{mg} / \mathrm{mL}$ of ACE. The reaction was started by the addition of $200 \mu \mathrm{L}$ of $150 \mathrm{mM}$ Tris-base buffer (pH 8.3) containing $1.125 \mathrm{M} \mathrm{NaCl}$ and 10 $\mathrm{mM}$ Abz-Gly-Phe-(NO$\left.)_{2}\right)$-Pro. At the end, the reaction mixture was incubated at $37^{\circ} \mathrm{C}$ for 60 min. The release of o-aminobenzoylglycine (Abz-gly) by the action of ACE generated a fluorescence that was measured at $355 \mathrm{~nm}$ excitation and $405 \mathrm{~nm}$ emission wavelengths, respectively. ACE inhibition of each collected fraction is expressed as a percentage. Çemen paste was also analyzed to test ACE inhibitory activity. Five grams of çemen paste was mixed with $20 \mathrm{~mL}$ of $0.01 \mathrm{~N} \mathrm{HCl}$, centrifuged (çemen paste concentration in this extract was 0.25 $\mathrm{g} / \mathrm{mL}$ ) and $50 \mu \mathrm{L}$ of the supernatant was subjected to analysis as indicated above. This supernatant was also used for antioxidant activity assays. .

\subsection{Antioxidant activity}

\subsubsection{2,2-Diphenyl-1-picrylhydrazylradical-scavenging assay}

2,2-Diphenyl-1-picrylhydrazyl (DPPH) radical-scavenging activity was measured in triplicate as described by Bersuder, Hole, and Smith (1998). The DPPH radical-scavenging activity (\%) was calculated as:

DPPH activity $(\%)=\left[\left(\mathrm{Abs}_{\text {control }}-\mathrm{Abs}_{\text {sample }}\right) / \mathrm{Abs}_{\mathrm{control}}\right] \times 100$

where, $\mathrm{Abs}_{\text {sample }}$ is the absorbance of sample and $\mathrm{Abs}_{\text {control }}$ is the absorbance of the control..

\subsubsection{Ferric-reducing antioxidant power (reducing power)}

The assay was based on the method described by Huang, Tsai, and Mau (2006). Distilled water and BHT was used as the negative control and positive control, respectively. .

\subsection{Statistical analysis}


The analysis of variance (ANOVA) procedure was conducted and significant differences in contents of free amino acid and peptides content between sampling time were evaluated by Tukey HSD Multiple Comparison Test using SPPS software (SPSS 17.0 for Windows, SPSS Inc, Chicago, IL, USA) $(p<0.05)$.

\section{Results and Discussion}

\subsection{Characterization of the Pastırma product}

\subsubsection{Moisture and sodium contents}

In the production of dried-cured meat products, due to the fast sodium chloride diffusion during processing, muscle proteins were solubilized and water activity was reduced, resulting in an ultimate product with a pleasant salty taste (Martin, 2001). During process stages at day 2, 5, 10 , and 21 , moisture contents of whole Pastırma samples were $69.6 \% \pm 1.01,68.6 \% \pm 1.45$, $62.6 \% \pm 1.48$ and $52.4 \% \pm 2.10$, respectively while samples from the inside parts showed a sodium content (determined on dry basis) of $14.54 \pm 4.65 \% ; 11.06 \pm 3.01 ; 11.58 \pm 2.89 \%$; and $11.25 \pm 2.14 \%$, respectively, and samples from the surface $16.60 \pm 3.48 \%$; $12.15 \pm 2.52 \%$; $8.68 \pm 2.13 \%$; and $8.36 \pm 2.25 \%$, respectively.

\subsubsection{Free amino acids and peptide contents}

Glutamine, alanine, taurine, lysine and leucine were the predominant amino acids identified at day 2, constituting 27.2\%, 15.9\%, 8.19\%, 5.97\% and 5.75\% of total FAAs, respectively (Table 1). Although curing was initiated at this stage, the samples had similar FAA to raw meat reported in the literature because of the short period of time the meat remained in the curing agents. At day 5, as in the first stage of processing, alanine, glutamine, lysine, leucine and taurine were predominant amino acids with some changes in their ratios. The predominant amino acids determined at day 10 were lysine, alanine, arginine, proline and glutamic acid. 
Concentrations of serine, asparagine, arginine, proline and all essential amino acids at day 10 increased in comparison to the amounts at days 2 and 5, with the exception of threonine and isoleucine $(\mathrm{p}<0.05)$. The most abundant FAA at day 21 was proline, followed by lysine, alanine, leucine, arginine and glutamic acid. Ceylan and Aksu (2011) reported that glutamine, tyrosine, lysine, glutamic acid, leucine and arginine were other predominant FAA in Pastırma. There were differences in the amounts of individual FAA in the aforementioned study and those in the present study, likely because of the differences in the source of samples.

The concentration of all individual amino acids increased during processing between 2 (glycine, $\beta$-alanine and alanine) and 20 (proline) times, except for taurine and glutamine. Taurine, a bioactive compound in meat (Arihara \& Ohata, 2008) possessing antioxidant and radioprotective characteristics (Huxtable, 1992), did not exhibit significant changes during processing because this compound is not part of proteins (Purchas, Rutherfurd, Pearce, Vather \& Wilkinson, 2004). Glutamine showed significant decreases during Pastırma processing because of its degradation to glutamic acid and $\mathrm{NH}_{3}$ (Young, Frost, \& Agnew, 2012). Similarly, Flores et al. (1997) reported a decrease in glutamine during short and long processes of Spanish Serrano dry-cured ham.

Total FAA contents increased over time $(\mathrm{p}<0.05)$. The most noticeable increases were observed during later stages of processing, i.e. after days 10 and 21. Overall, when changes in FAA contents are considered, it is obvious that there is an intense proteolysis during Pastırma processing. Changes in FAA content at the earlier stages of processing are not that prominent because degradation of peptides to FAA occurs at the later stages of the proteolysis phenomena (Toldrá, 1998).

Increase in the relative carnosine and anserine content was observed during processing until day 10 , and then, both decreased at day 21. This decrease in the relative carnosine content could 
be attributed to the incorporation of çemen paste in the process steps after day 10. Çemen paste did not contain carnosine and anserine (Table 1). Carnosine and anserine as the most abundant antioxidants in meats (Arihara \& Ohata, 2008), are considered bioactive peptides because of their important role in the prevention of stress related diseases, wound healing recovery from fatigue, and reducing certain proteolytic reactions associated with cell ageing (Arihara \& Ohata, 2008; Hipkiss, Brownson, Bertani, Ruiz, \& Ferro, 2002).

In the present study, besides dipeptides, carnosine and anserine, the profile of other peptides generated during processing of Pastırma was studied using MALDI-TOF mass spectrometry.

\subsection{Peptide-mass mapping by MALDI-TOF MS}

MALDI-TOF MS spectra are shown in Figure 2 and in Figure 3. Proteolysis stages can also be confirmed by the gel view given at the top of figures that were obtained using mMass software, which can be used to effectively compare the ions detected at different sampling times.

The first spectrum obtained at day 2 of processing indicates the initial peptide profile after incorporating curing agents into the meat. This spectrum represents peptides naturally present in meat and those resulting from the first steps of protein degradation. At day 5, an intensive accumulation of peptides was clearly observed, which supports FAA contents at this stage where slight increases were observed in the concentration of individual FAAs (Table 1). The peptide profile at day 10 showed a decrease in the amount of ions detected in comparison to the peaks obtained at day 5, probably due to the breakdown of 800 - 2000 Da peptides to smaller ones and FAAs. Overall, the peptide profiles obtained during various stages of Pastirma processing include a mixture of peptides present in a wide range of molecular masses. A fair distribution of peptides from 800 to $2000 \mathrm{~m} / \mathrm{z}$ was obtained at all different times of processing 
(Figure 2). Differences in the spectra between Day 2 and Day 21 were also analyzed in detail by mMass software. In fact, 29 peptides were newly generated at Day 21.

MALDI-TOF MS spectra was also determined in the inside and surface part of the final product (see in Figure 3). In comparison to the inside parts, the spectra obtained from the surface showed a higher amount in peptides probably due to the influence of processing parameters such as temperature, humidity, or çemen paste that directly affects the surface of the sample.

\subsection{Isolation of the peptides by size exclusion chromatography and bioactive study}

Size-exclusion chromatography (SEC) with Sephadex G25 gel filtration column was used for fractionation of the peptide mixture according to their size. Collected fractions were monitored by ultraviolet (UV) absorption at $214 \mathrm{~nm}, 254 \mathrm{~nm}$ and $280 \mathrm{~nm}$. Figure 5a shows the obtained chromatogram from the elution volumes $100 \mathrm{~mL}$ (20 ${ }^{\text {th }}$ fraction) to $600 \mathrm{~mL}$ (120 $0^{\text {th }}$ fraction), that were those showing any response (absorbance signal). The absorbance signal in the chromatograms is saturated since a high amount of the sample was injected to ensure the detection of the ACE and antioxidant activity in the fractions and also, to know the approximate size of the peptides having these activities.

ACE-I inhibitory properties of fractions are presented in Figure 4. ACE inhibitory values of inside, surface and whole samples of the final product varied from $0 \%$ to $99.5 \%$ (negative values of inside samples showed no activity). Maximum activity was observed in the fractions between 220 and $270 \mathrm{~mL}$ in whole, inside and surface samples, ranging between 72.9-99.5\%, 63.9-99.9\% and 80.1-99.9\%, respectively. These fraction volumes correspond to molecular masses between 900 and 1500 Da (results not shown). The fractions eluted before and after these volume ranges exhibited lower ACE inhibitory activity. Also, in the surface sample, activity of fractions eluting from 130 to $210 \mathrm{~mL}$ was relatively high (between 40 and 65\%). On the other hand, DPPH radical-scavenging activity from $60 \%$ in the elution zone between 250 
and $300 \mathrm{~mL}$ was observed for a whole sample (Figure 5B). These volumes correspond to molecular masses between 700 and 2000 Da (results not shown). Escudero et al. (2012) noted that Spanish dry-cured ham is rich in antioxidant peptides naturally generated during the drycuring process, with a strong DPPH radical-scavenging activity in the elution zone between 220 and $345 \mathrm{~mL}$ (radical-scavenging activity from 39\% to 92\%). It was emphasized that possible factors responsible for greater antioxidant activity were adequate length, amino acid composition, and amino acid position in the sequence (Mora et al., 2014). Figure 5C shows main results obtained for ferric reducing power in the SEC fractions of Pastırma. The strongest antioxidant power was monitored in the elution area between 230 and $320 \mathrm{~mL}$. In this area, whole samples demonstrated generally the higher antioxidant power with absorbance values greater than 0.94 .

Within the sample parts evaluated, surface samples appeared to be the most active in ACEinhibitory and antioxidant assays, probably due to the effect of çemen paste applied on the surface of the product. ACE inhibitory activity of çemen paste would result from the components, fenugreek, garlic and pepper. Hamden, Kesskes, Belhaj, Mnafgui, and Allouche (2011) reported that fenugreek seeds represent a significant antihypertensive effect which arises from its essential oil composition. ACE inhibitor dipeptides derived from garlic have already been isolated and characterized (Suetsuna, 1998). Both dried and aqueous extracts as well as wild garlic have a significant blood pressure lowering effect (Hosseini, Shafiee, \& Baluchnejadmojarad, 2007; Sendl et al., 1992; Sharifi, Darabi, \& Akbarloo, 2003). At the same, many paprika species exhibit anti-hypertension activity (Ranilla, Kwon, Apostolidis, \& Shetty, 2010). Thus, although çemen paste was removed before ACE-inhibitory analysis, some of these compounds could have migrated to the meat resulting in higher activities in its surface. As in the case of ACE-inhibitory activity, natural antioxidant compounds could have diffused in the meat due to their miscibility in the fatty fraction allowing the enrichment of the surface in 
natural antioxidants. Regarding volumes of fractions, small peptides represented the highest antioxidant activity, which is in agreement with the results obtained in the ACE inhibitory activity assay. The ACE inhibitory effect as well as the antioxidant activity observed might have resulted from the synergistic effect of çemen ingredients together with the generated peptides. In fact, çemen paste has been previously described as antimicrobial against Escherichia coli, Staphylococcus aureus and Yersinia enterocolitica showing a higher activity than the individual ingredients, probably due to the synergistic effect between compounds (Yetim, Sagdic, Dogan \& Ockerman, 2013).

Meat is a good source of bioactive peptides (Arihara, Nakashima, Mukai, Ishikawa, \& Itoh, 2001; Escudero et al., 2012; Katayama et al., 2003; Mora, Aristoy \& Toldrá, 2016), and among processed meat products dry-cured ham is the only product reported as a natural source of antihypertensive and antioxidant peptides (Arihara \& Ohata, 2008; Escudero et al., 2012). Escudero et al. (2012) succeeded in identifying three novel peptides from Spanish dry-cured ham possessing in vivo antihypertensive activity. High stability of these ACE inhibitory ham peptides during heat treatment and in vitro gastrointestinal digestion were also proved by Escudero et al., (2014).

In the current study, strong inhibition of ACE probably resulted from high concentrations of amino acids, i.e. proline, alanine and leucine in certain positions of the generated peptides in final Pastırma product. What is more, main differences observed in inside and surface samples in comparison with whole sample could be due to a synergistic effect occurred between the generated bioactive peptides and the çemen paste.

\subsection{Characterization of çemen paste}

Çemen paste is used to cover the pastirma and influences both flavour and preservation of the final product. Thus, this mixture of ingredients has been reported to contribute to the color, 
texture, and flavor of pastirma, as well as has resulted very effective against microbial contamination and preventing excessive drying during its processing. FAA contents (Table 1), sodium content, ACE-I inhibitory activity, DPPH radical scavenging and ferric reducing antioxidant power of çemen paste (Table 2) were also analyzed in this study. Çemen paste showed $4.87 \%$ sodium and $1007.86 \mathrm{mg} / 100 \mathrm{~g}$ (dry matter) of total FAA content. The most abundant amino acids found in çemen paste were arginine, proline, asparagine, glutamic acid and lysine. ACE-I inhibitory activity of çemen paste was $93.75 \%$ at $0.25 \mathrm{~g} / \mathrm{mL}$ (Table 2) which was close to maximum activity determined in particular peptide fractions of Pastırma samples (Figure 4). The higher percentages of ACE inhibitory activity obtained in surface sample could be due to the action of çemen paste. DPPH radical scavenging and ferric reducing antioxidant power of $0.25 \mathrm{~g} / \mathrm{mL}$ çemen paste were found to be $89 \%$ and 0.88 (absorbance value), respectively (Table 2). These values indicate that the high antioxidant capacity of çemen paste could influence the strong antioxidant activity of Pastırma products.

\section{Conclusions}

Intense proteolysis during processing of Pastırma evidenced by a significant increase in free amino acids and peptides content was monitored by using modern proteomic techniques in this novel study. Formation of peptides in a wide range of molecular masses that were naturally generated during dry-cured processing was confirmed by MALDI-TOF spectra. The water soluble peptide fraction of Pastırma showed an ACE inhibitory activity higher than $86 \%$ in SEC fraction corresponding to molecular masses between 900 and $1500 \mathrm{Da}$, and also a strong DPPH radical-scavenging activity above $60 \%$ corresponding to molecular masses between 700 and 2000 Da. The promising results from this work showed that Pastırma represents a good source of natural bioactive peptides capable of reducing free radicals and inhibiting ACE activity. The novel scientific gains from the current study will be a guide for further studies on the 
identification, quantification and sequencing of bioactive peptides of Pastırma by mass spectrometry in tandem.

\section{Acknowledgements}

Grant AGL2014-57367-R from MINECO (Spain) and FEDER funds and JAEDOC-CSIC postdoctoral contract of L.M. cofounded by the European Social Found are acknowledged. The research fellowship grant provided by Erasmus+KA1 Student Mobility Programme for Higher Education for the author Ebru Deniz is also gratefully acknowledged. MALDI-TOF analysis was carried out by in the SCSIE University of Valencia Proteomics Unit (Spain), a member of ISCIII ProteoRed Proteomics Platform. Authors would like to thank the helpful support of Carolina Diaz Noriega as technician.

\section{References}

Ahhmed, A.M. (2013). Traditional cured meat-making process degrades the proteins of $M$. latissimus dorsi of bovine. International Food Research Journal 21, 139-148.

Ahhmed, A.M., Kaneko, G., Ushio, H., Inomata, T., Yetim, H. Karaman, S., Mugurumad, M., \& Sakata, R. (2013). Changes in physicochemical properties of proteins in Kayserian Pastirma made from the $M$. semimembranosus muscle of cows during traditional processing. Food Science and Human Wellness 2, 46-55.

Ahhmed, A.M., Kaneko, G., Ushio, H., Karaman, S., Inomata, T., Sakata, R., \& Yetim, H. (2014). Proteins degradation value in cured meat product made from M. Cutaneous-omo brachialis muscle of bovine. European Food Research and Technology, 238(3), 387396.

Aksu, M.I. (1999). Research on the possibility of starter culture use in Pastırma production (Pastırma uretiminde starter kultur kullanim imkanlari) Ph.D. Thesis, Erzurum, Turkey. 
Arihara, K., Nakashima, Y., Mukai, T., Ishikawa, S., \& Itoh, M. (2001). Peptide inhibitors for angiotensin I-converting enzyme from enzymatic hydrolysates of porcine skeletal muscle proteins. Meat Science, 57(3), 319-324.

Arihara, K., \& Ohata, M. (2008). Bioactive compounds in meat Meat biotechnology (pp. 231249): Springer.

Aristoy, M.C., \& Toldrá, F. (1991). Deproteinization techniques for HPLC amino acid analysis in fresh pork muscle and dry-cured ham. Journal of Agricultural and Food Chemistry, 39(10), 1792-1795.

Aristoy, M.C., \& Toldrá, F. (1995). Isolation of flavor peptides from raw pork meat and drycured ham. Developments in Food Science, 37, 1323-1344.

Armenteros, M., Aristoy, M.-C., Barat, J.M., \& Toldrá, F. (2012). Biochemical and sensory changes in dry-cured ham salted with partial replacements of $\mathrm{NaCl}$ by other chloride salts. Meat science, 90(2), 361-367.

Bersuder, P., Hole, M., \& Smith, G. (1998). Antioxidants from a heated histidine-glucose model system. I: Investigation of the antioxidant role of histidine and isolation of antioxidants by high-performance liquid chromatography. Journal of the American Oil Chemists' Society, 75(2), 181-187.

Bidlingmeyer, B., Cohen, S., Tarvin, T., \& Frost, B. (1986). A new, rapid, high-sensitivity analysis of amino acids in food type samples. Journal-Association of Official Analytical Chemists, 70(2), 241-247.

Ceylan, S., \& Aksu, M.İ. (2011). Free amino acids profile and quantities of 'sirt', 'bohca'and 'sekerpare' pastirma, dry cured meat products. Journal of the Science of Food and Agriculture, 91(5), 956-962. 
Chernukha, I.M., Fedulova, L.V., \& Kotenkova, E.A. (2015). Meat by-product is a Source of Tissue-specific Bioactive Proteins and Peptides against Cardio-vascular Diseases. Procedia Food Science, 5, 50-53.

Escudero, E., Aristoy, M.C., Nishimura, H., Arihara, K., \& Toldrá, F. (2012). Antihypertensive effect and antioxidant activity of peptide fractions extracted from Spanish dry-cured ham. Meat science, 91(3), 306-311.

Escudero, E., Mora, L., \& Toldrá, F. (2014). Stability of ACE inhibitory ham peptides against heat treatment and in vitro digestion. Food chemistry, 161, 305-311.

Escudero, E., Toldrá, F., Sentandreu, M.A., Nishimura, H., \& Arihara, K. (2012). Antihypertensive activity of peptides identified in the in vitro gastrointestinal digest of pork meat. Meat science, 91(3), 382-384.

Flores, M., Aristoy, M., Spanier, A.M., \& Toldrá, F. (1997). Non-Volatile Components Effects on Quality of “Serrano” Dry-cured Ham as Related to Processing Time. Journal of Food Science, 62(6), 1235-1239.

Gök, V., Obuz, E., \& Akkaya, L. (2012). Turkish pastirma -A dry cured beef product Handbook of Meat and Meat Processing (pp. 40-689-697 pp,): CRC Press.

Hamden, K., Keskes, H., Belhaj, S., Mnafgui, K., \& Allouche, N. (2011). Inhibitory potential of omega-3 fatty and fenugreek essential oil on key enzymes of carbohydrate-digestion and hypertension in diabetes rats. Lipids in health and disease, 10(1), 1.

Hipkiss, A.R., Brownson, C., Bertani, M.F., Ruiz, E., \& Ferro, A. (2002). Reaction of carnosine with aged proteins. Annals of the New York Academy of Sciences, 959(1), 285-294.

Hosseini, M., Shafiee, S.M., \& Baluchnejadmojarad, T. (2007). Garlic extract reduces serum angiotensin converting enzyme (ACE) activity in nondiabetic and streptozotocindiabetic rats. Pathophysiology, 14(2), 109-112. 
Huang, S.-J., Tsai, S.-Y., \& Mau, J.-L. (2006). Antioxidant properties of methanolic extracts from Agrocybe cylindracea. LWT-Food Science and Technology, 39(4), 379-387.

Huxtable, R. (1992). Physiological actions of taurine. Physiol rev, 72(1), 101-163.

Katayama, K., Tomatsu, M., Fuchu, H., Sugiyama, M., Kawahara, S., Yamauchi, K., . . . Muguruma, M. (2003). Purification and characterization of an angiotensin I-converting enzyme inhibitory peptide derived from porcine troponin C. Animal Science Journal, 74(1), 53-58. doi: 10.1046/j.1344-3941.2003.00086.x

Kız1lkaya, E. (2012). Proteolytic changes during reduced sodium Pastırma Processing. Master Thesis, Ankara University, Ankara, Turkey.

Korhonen, H., \& Pihlanto, A. (2003). Food-derived bioactive peptides-opportunities for designing future foods. Current pharmaceutical design, 9(16), 1297-1308.

Lametsch, R., Karlsson, A., Rosenvold, K., Andersen, H.J., Roepstorff, P., \& Bendixen, E. (2003). Postmortem proteome changes of porcine muscle related to tenderness. Journal of Agricultural and Food Chemistry, 51(24), 6992-6997.

Lassoued, I., Mora, L., Nasri, R., Aydi, M., Toldrá, F., Aristoy, M. C., ... \& Nasri, M. (2015). Characterization, antioxidative and ACE inhibitory properties of hydrolysates obtained from thornback ray (Raja clavata) muscle. Journal of proteomics, 128, 458-468.

Martin, M. (2001). Meat curing technology. In Y. H. Hui, W. K. Nip, R. W. Rogers \& A. O. Young (Eds.), Meat science and applications (pp. 491-508). New York: Marcel Dekker.

Matsui, T., \& Matsumoto, K. (2006). Antihypertensive peptides from natural resources. Advances in Phytomedicine, 2, 255-271.

Mora, L., Aristoy, M., \& Toldrá, F. (2016). Bioactive Peptides in Foods Encyclopedia of Food and Health. 
Mora, L., Escudero, E., Fraser, P., Aristoy, M., \& Toldrá, F. (2014). Proteomic identification of antioxidant peptides from 400 to 2500Da generated in Spanish dry-cured ham contained in a size-exclusion chromatography fraction. Food Research International, $56,68-76$.

Mora, L., Sentandreu, M.A., Fraser, P.D., Toldrá, F., \& Bramley, P.M. (2009). Oligopeptides arising from the degradation of creatine kinase in Spanish dry-cured ham. Journal of agricultural and food chemistry, 57(19), 8982-8988.

Mora, L., Sentandreu, M.A., Koistinen, K.M., Fraser, P.D., Toldrá, F., \& Bramley, P.M. (2009). Naturally generated small peptides derived from myofibrillar proteins in Serrano drycured ham. Journal of agricultural and food chemistry, 57(8), 3228-3234.

Öztan, A. (2005). Et Bilimi ve Teknolojisi. Ankara, Turkey: Gıda Mühendisliği Odası Yayınları. Pihlanto-Leppälä, A. (2000). Bioactive peptides derived from bovine whey proteins: opioid and ace-inhibitory peptides. trends in Food Science \& technology, 11(9), 347-356.

Purchas, R., Rutherfurd, S., Pearce, P., Vather, R., \& Wilkinson, B. (2004). Concentrations in beef and lamb of taurine, carnosine, coenzyme Q 10, and creatine. Meat Science, 66(3), 629-637.

Ranilla, L.G., Kwon, Y.-I., Apostolidis, E., \& Shetty, K. (2010). Phenolic compounds, antioxidant activity and in vitro inhibitory potential against key enzymes relevant for hyperglycemia and hypertension of commonly used medicinal plants, herbs and spices in Latin America. Bioresource technology, 101(12), 4676-4689.

Sendl, A., Elbl, G., Steinke, B., Redl, K., Breu, W., \& Wagner, H. (1992). Comparative pharmacological investigations of Allium ursinum and Allium sativum. Planta medica, 58(1), 1-7. 
Sentandreu, M., Stoeva, S., Aristoy, M., Laib, K., Voelter, W., \& Toldrá, E. (2003). Identification of Small Peptides Generated in Spanish Dry-cured Ham. Journal of Food Science, 68(1), 64-69.

Sentandreu, M., \& Toldrá, F. (2001). Dipeptidyl peptidase activities along the processing of Serrano dry-cured ham. European Food Research and Technology, 213(2), 83-87.

Sentandreu, M.Á., \& Toldrá, F. (2006). A rapid, simple and sensitive fluorescence method for the assay of angiotensin-I converting enzyme. Food chemistry, 97(3), 546-554.

Sforza, S., Pigazzani, A., Motti, M., Porta, C., Virgili, R., Galaverna, G., . . . Marchelli, R. (2001). Oligopeptides and free amino acids in Parma hams of known cathepsin B activity. Food Chemistry, 75(3), 267-273.

Sharifi, A.M., Darabi, R., \& Akbarloo, N. (2003). Investigation of antihypertensive mechanism of garlic in 2K1C hypertensive rat. Journal of ethnopharmacology, 86(2), 219-224.

Soyer, A., Uğuz, Ş., \& Dalmış, Ü. (2011). Proteolytic changes during processing in Turkish dry-cured meat product (Pastırma) with different salt levels. Journal of Food Quality, 34(3), 212-219.

Suetsuna, K. (1998). Isolation and characterization of angiotensin I-converting enzyme inhibitor dipeptides derived from Allium sativum L (garlic). The Journal of Nutritional Biochemistry, 9(7), 415-419.

Toldrá, F. (1998). Proteolysis and lipolysis in flavour development of dry-cured meat products. Meat science, 49, S101-S110.

Toldrá, F., Aristoy, M.-C., \& Flores, M. (2000). Contribution of muscle aminopeptidases to flavor development in dry-cured ham. Food Research International, 33(3), 181-185.

Toldrá, F., Cerveró, M., \& Part, C. (1993). Porcine aminopeptidase activity as affected by curing agents. Journal of Food Science, 58(4), 724-726. 
Toldrá, F., \& Flores, M. (1998). The role of muscle proteases and lipases in flavor development during the processing of dry-cured ham. Critical Reviews in Food Science, 38(4), 331352.

Toldrá, F., Rico, E., \& Flores, J. (1993). Cathepsin B, D, H and L activities in the processing of dry-cured ham. Journal of the Science of Food and Agriculture, 62(2), 157-161.

Uğuz, Ş. (2007). Effects of salt content on proteolytic changes in Pastırma. Master Thesis, Ankara University, Ankara, Turkey.

Walther, B., \& Sieber, R. (2011). Bioactive proteins and peptides in foods. International Journal for Vitamin and Nutrition Research, 81(2), 181.

Yagli, H., \& Ertas, A. (1998). Effect of sodium ascorbate on some quality characteristics of Turkish pastirma. Turkish Journal of Agriculture and Forestry, 22, 515-520.

Yetim, H., Sagdic, O., Dogan, M., Ockerman, H.W. (2006). Sensitivity of three pathogenic bacteria to Turkish cemen paste and its ingredients. Meat Science, 74, 354-358.

Young, O.A., Frost, D.A., \& Agnew, M. (2012). Analytical Methods for Meat and Meat Products. In Y. Hui (Ed.), Handbook of Meat and Meat Processing: CRC Press.

\section{FIGURE CAPTIONS}

Figure 1 Pastırma processing flow.

Figure 2 MALDI-TOF MS spectra of peptides generated at days 2, 5, 10 and 21 of Pastırma processing. Spectrum displays molecular masses between 800 and $2000 \mathrm{~m} / \mathrm{z}$. Numbers indicate $\mathrm{m} / \mathrm{z}\left(\left[\mathrm{MH}^{+}\right]\right)$of the peptides.

Figure 3 MALDI-TOF spectra of end product at 21 days in the inside and the surface of the Pastırma. Spectrum displays molecular masses between 800 and $2000 \mathrm{~m} / \mathrm{z}$. Numbers indicate $m / z\left(\left[\mathrm{MH}^{+}\right]\right)$of the peptides. 
Figure 4 ACE-inhibitory activity of fractions collected on a Sephadex G-25 gel filtration column from Pastırma extracts.

Figure 5 (a) UV absorbance values of peptide elution volumes from $100 \mathrm{~mL}$ to $600 \mathrm{~mL}$ at 214 nm after fractionation of Pastırma extracts on a Sephadex G-25 gel filtration column; (b) DPPH radical-scavenging activity of the obtained fractions; (c) Ferric-reducing antioxidant power of the obtained fractions. 


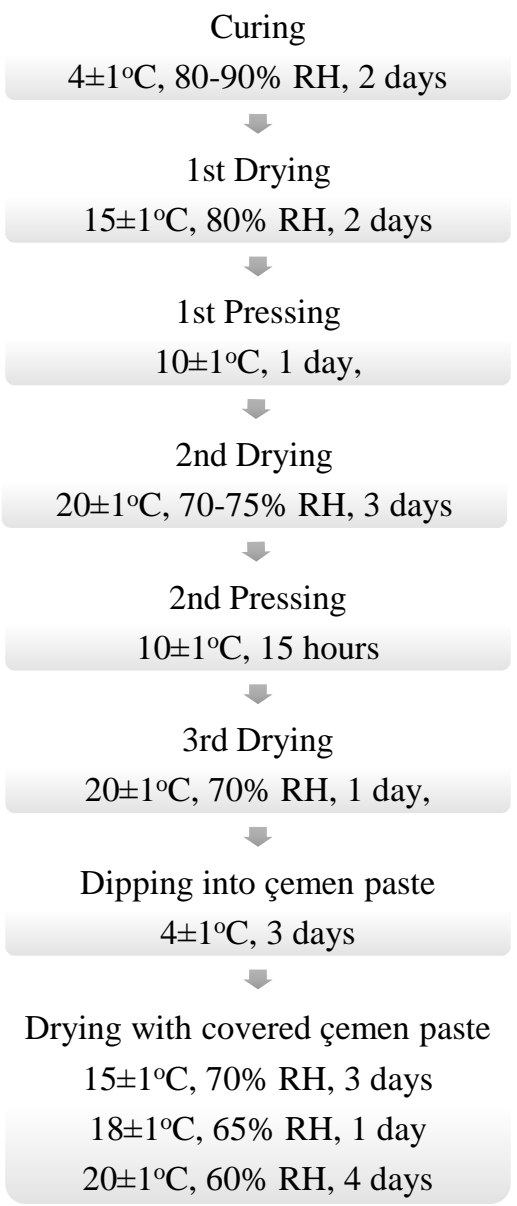

Figure 1 Pastırma processing flow 


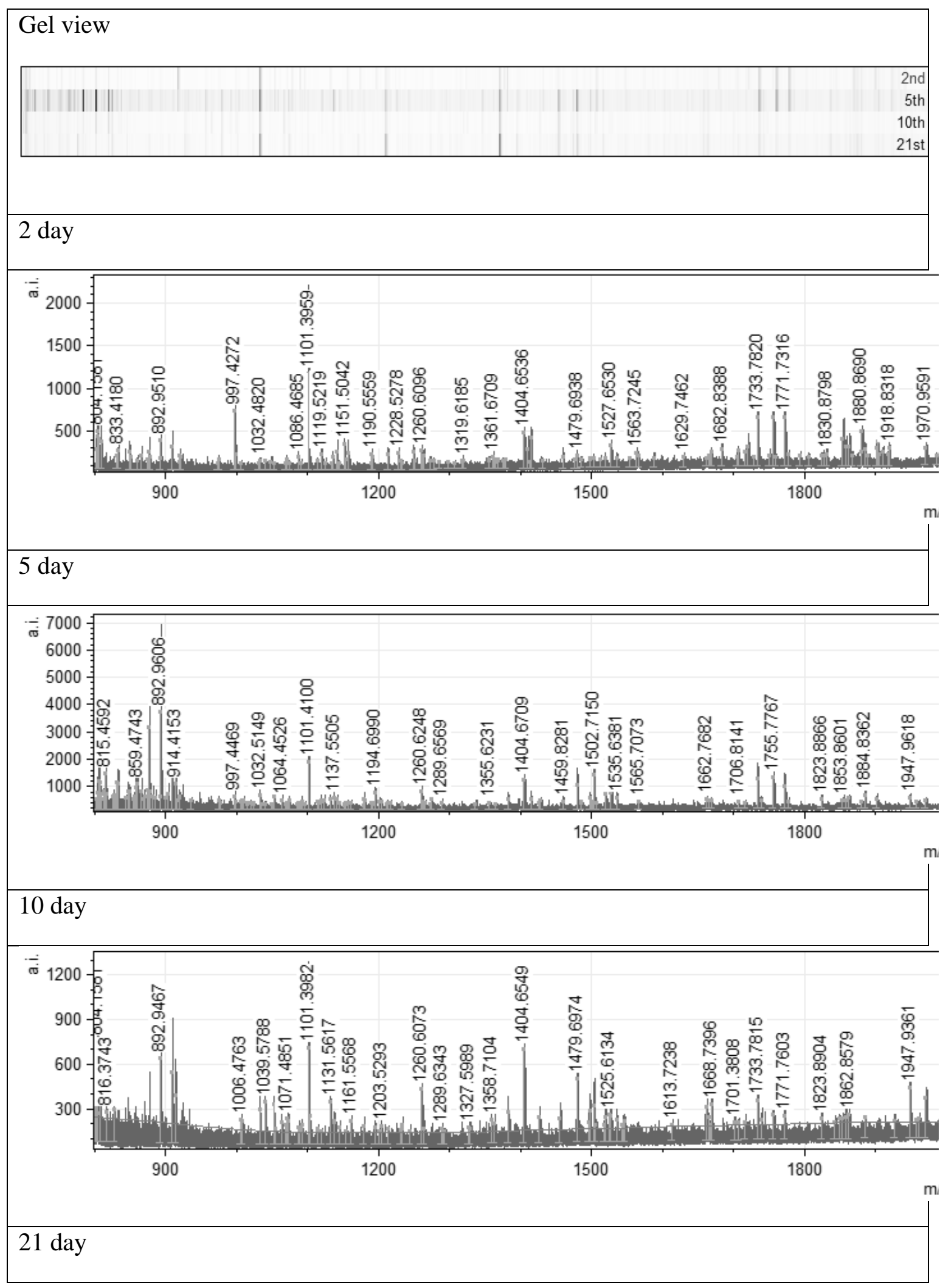




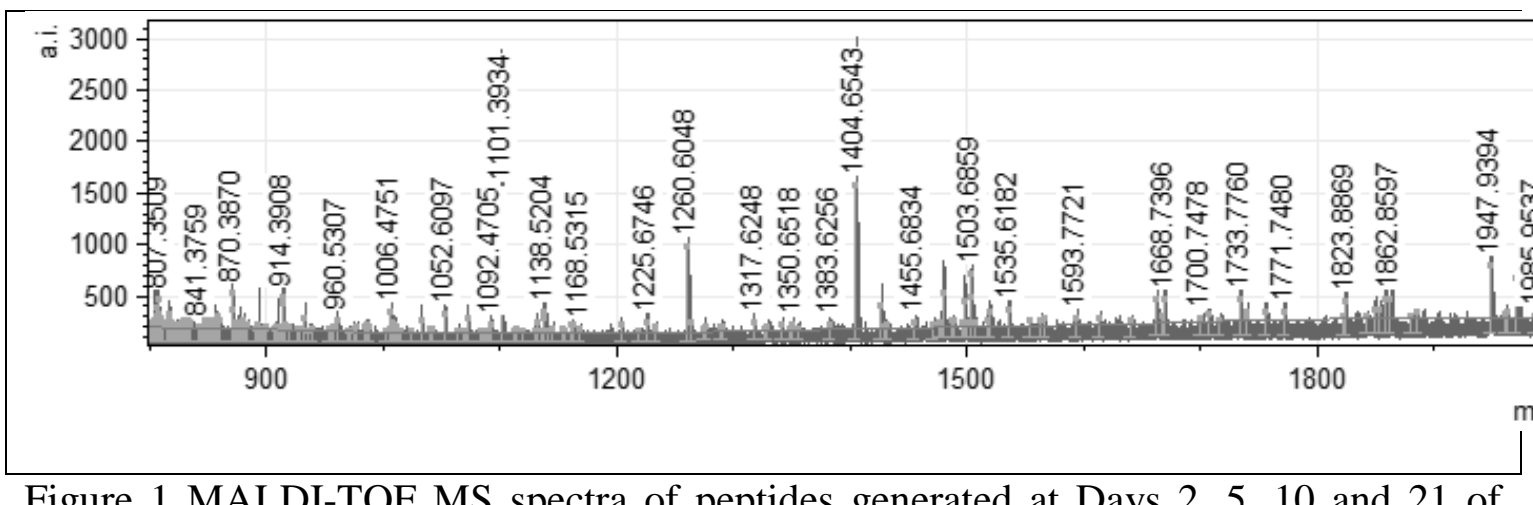

Figure 1 MALDI-TOF MS spectra of peptides generated at Days 2, 5, 10 and 21 of pastırma processing. Spectrum displays molecular masses between 800 and 2000 Da. Numbers indicate $\mathrm{m} / \mathrm{z}\left(\left[\mathrm{MH}^{+}\right]\right)$of the peptides. Gel view was obtained by using mMass software. 


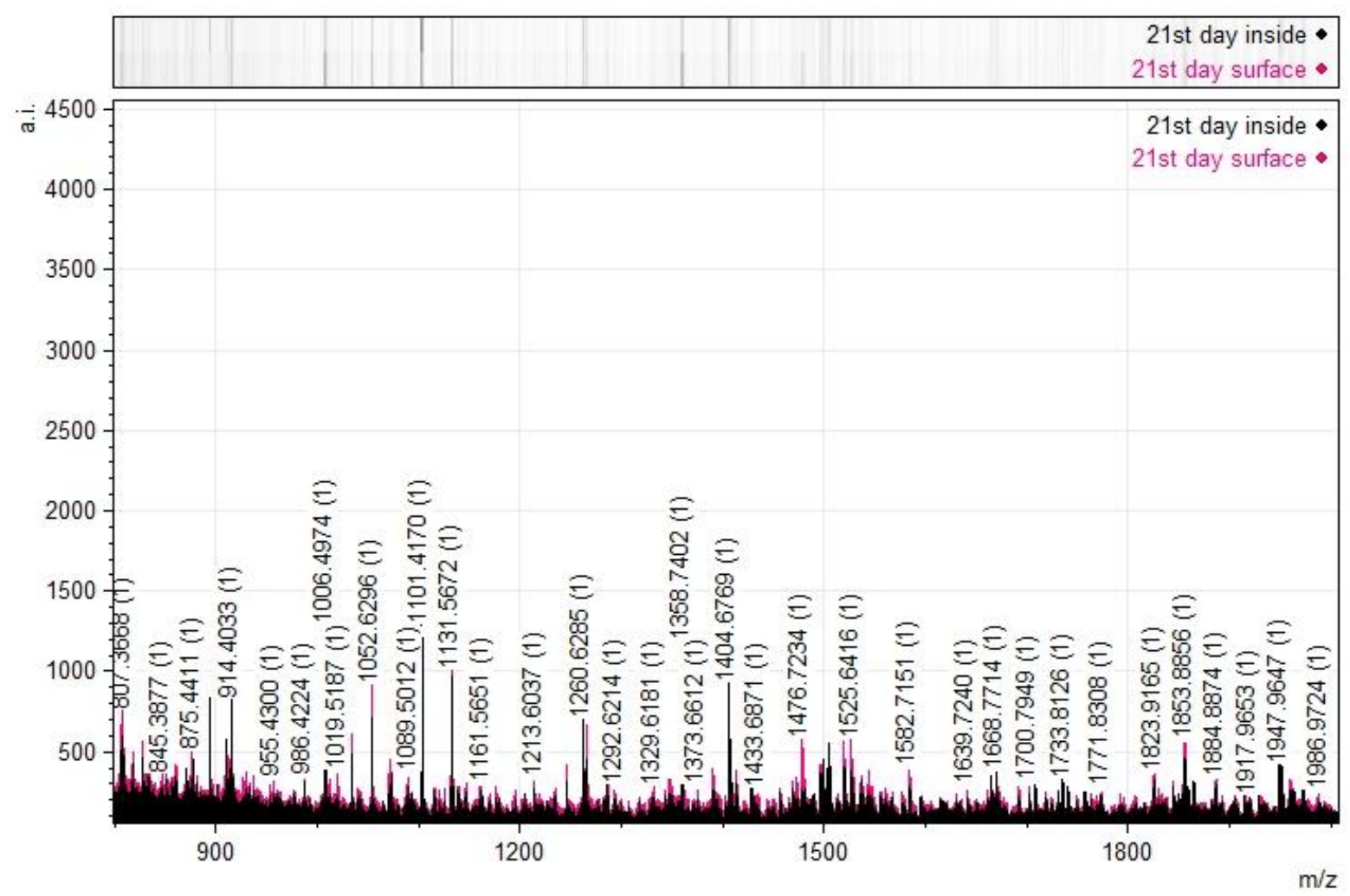

Figure 1 MALDI-TOF M $\underline{S} s$ spectra of end product inside and surface. Spectrum displays molecular masses between 800 and $2000 \mathrm{Da}$. Numbers indicate $\mathrm{m} / \mathrm{z}\left(\left[\mathrm{MH}^{+}\right]\right)$of the peptides. Gel view was obtained using mMass software 
Figure 4

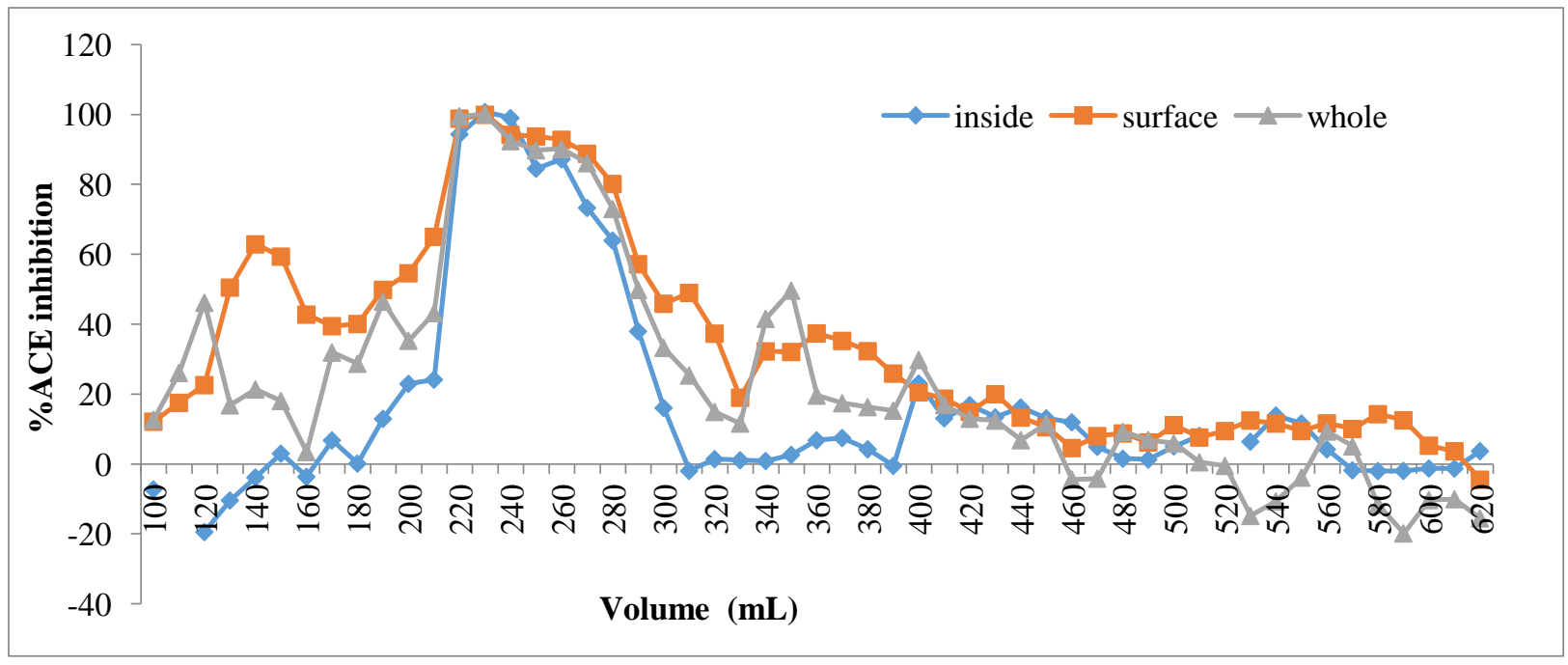

Figure 1 ACE-inhibitory activity of fractions collected on a Sephadex G-25 gel filtration column from pastırma extracts 


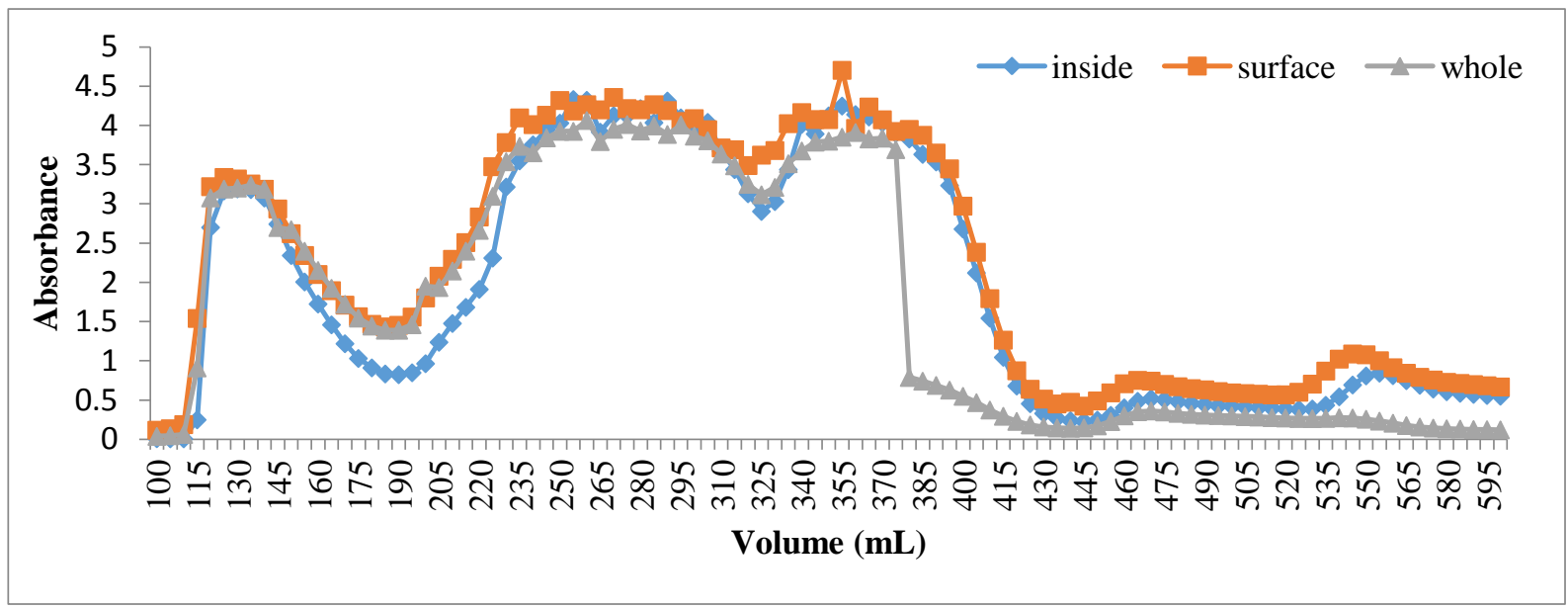

(a)

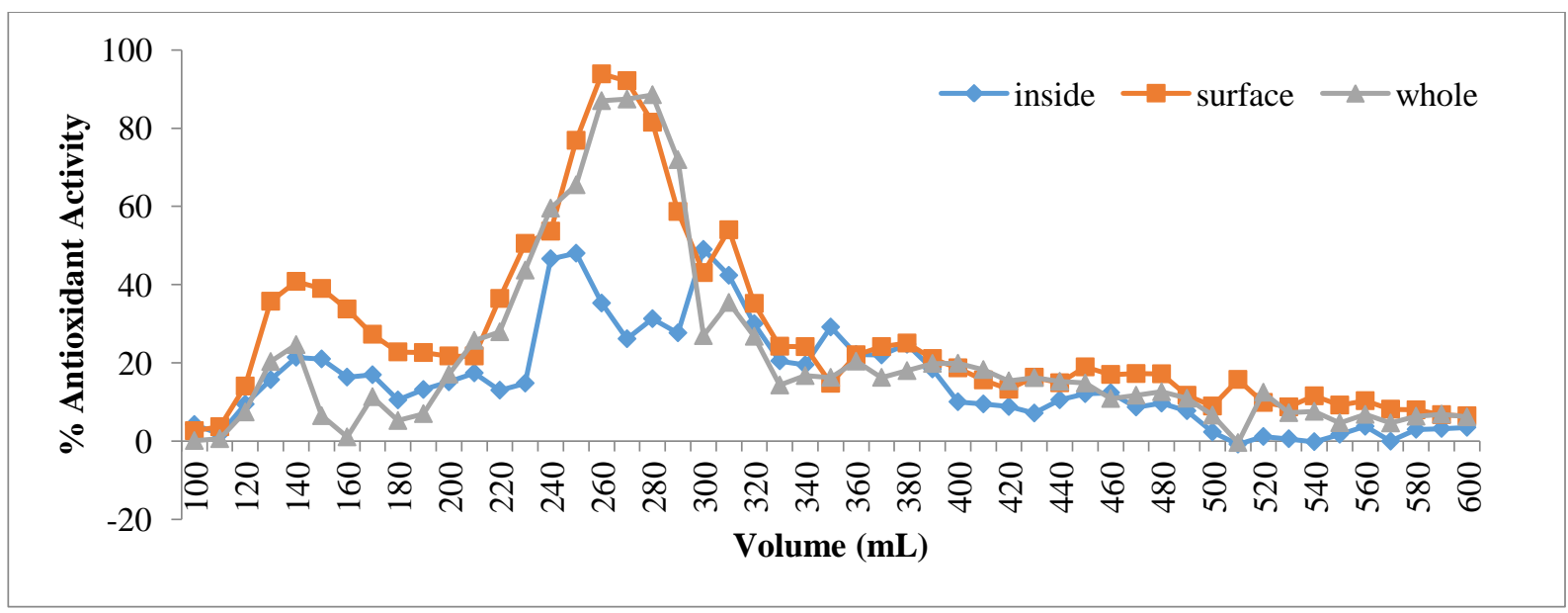

(b)

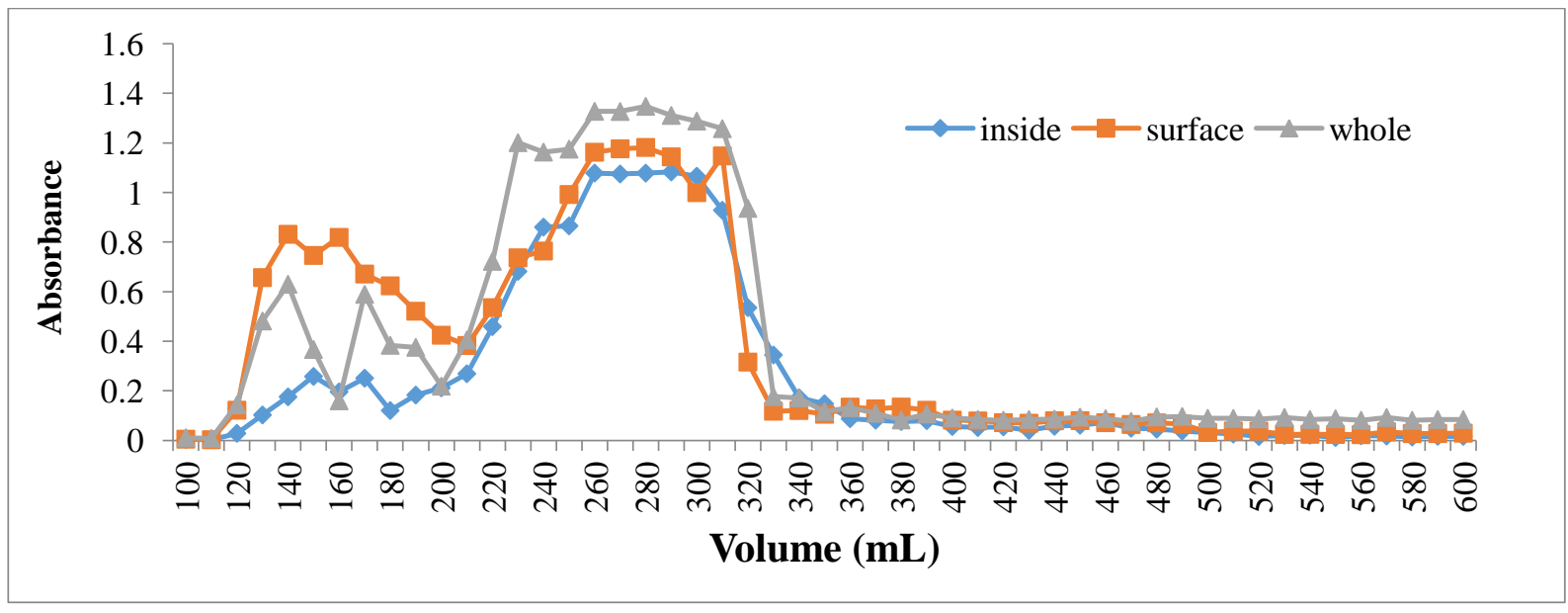

(c)

Figure 1 (a) UV absorbance values of peptide elution volumes from $100 \mathrm{~mL}$ ( $20^{\text {th }}$ fraction) to $600 \mathrm{~mL}\left(120^{\text {th }}\right.$ fraction) at $214 \mathrm{~nm}$ after fractionation of pastırma extracts on a Sephadex G-25 gel filtration column; (b) DPPH radical-scavenging activity of these fractionated peptides (c) Ferric-reducing antioxidant power of these fractionated peptides 

Table 1 Amino acid and natural dipeptide concentrations of Pastırma samples (mg per 100g of dry matter) at days 2, 5, 10 and 21, and çemen paste $(\mathrm{mg} / 100 \mathrm{~g}$ dry matter)*

\begin{tabular}{|c|c|c|c|c|c|}
\hline Amino acids & 2nd day & 5th day & 10th day & 21st day & Çemen paste \\
\hline \multicolumn{6}{|l|}{ Essential FAA } \\
\hline Histidine & $5.06^{\mathrm{a}} \pm 0.69$ & $10.26^{\mathrm{a}} \pm 2.18$ & $18.48^{\mathrm{b}} \pm 4.88$ & $28.45^{\mathrm{c}} \pm 6.70$ & $13.74 \pm 0.93$ \\
\hline Threonine & $9.47^{\mathrm{a}} \pm 0.44$ & $8.09^{\mathrm{ab}} \pm 1.71$ & $17.92^{\mathrm{b}} \pm 4.99$ & $41.66^{\mathrm{c}} \pm 10.33$ & $16.42 \pm 1.77$ \\
\hline Valine & $14.57^{\mathrm{a}} \pm 1.30$ & $26.06^{\mathrm{a}} \pm 3.44$ & $42.37^{\mathrm{b}} \pm 8.81$ & $84.02^{\mathrm{c}} \pm 15.21$ & $38.12 \pm 4.61$ \\
\hline Methionine & $8.17^{\mathrm{a}} \pm 1.10$ & $12.30^{\mathrm{a}} \pm 1.57$ & $19.24^{\mathrm{b}} \pm 3.65$ & $37.29^{c} \pm 5.25$ & $9.82 \pm 1.28$ \\
\hline Isoleucine & $12.63^{\mathrm{a}} \pm 1.19$ & $17.26^{\mathrm{ab}} \pm 2.01$ & $26.24^{\mathrm{b}} \pm 5.25$ & $56.98^{\mathrm{c}} \pm 9.73$ & $16.71 \pm 1.48$ \\
\hline Leucine & $21.78^{\mathrm{a}} \pm 1.86$ & $32.45^{\mathrm{a}} \pm 2.95$ & $49.84^{\mathrm{b}} \pm 9.57$ & $111.55^{\mathrm{c}} \pm 17.91$ & $30.03 \pm 3.55$ \\
\hline Phenylalanine & $11.09^{\mathrm{a}} \pm 1.16$ & $16.81^{\mathrm{a}} \pm 2.20$ & $31.1^{\mathrm{b}} \pm 5.87$ & $70.86^{\mathrm{c}} \pm 11.09$ & $24.23 \pm 2.72$ \\
\hline Tryptophan & $2.52^{\mathrm{a}} \pm 0.19$ & $3.65^{\mathrm{a}} \pm 0.57$ & $7.02^{\mathrm{b}} \pm 1.46$ & $14.33^{\mathrm{c}} \pm 2.41$ & $10.60 \pm 1.44$ \\
\hline Lysine & $22.61^{\mathrm{a}} \pm 3.12$ & $36.40^{\mathrm{a}} \pm 6.55$ & $88.12^{\mathrm{b}} \pm 21.21$ & $140.23^{\mathrm{c}} \pm 37.50$ & $70.00 \pm 13.25$ \\
\hline \multicolumn{6}{|c|}{ Non essential FAA } \\
\hline Aspartic acid & $1.35^{\mathrm{a}} \pm 0.21$ & $0.91^{\mathrm{a}} \pm 0.19$ & $3.14^{\mathrm{a}} \pm 0.93$ & $9.31^{\mathrm{b}} \pm 7.34$ & $24.99 \pm 3.06$ \\
\hline Glutamic acid & - & - & $55.74^{\mathrm{a}} \pm 5.84$ & $92.99^{\mathrm{b}} \pm 28.19$ & $76.31 \pm 9.62$ \\
\hline Serine & $12.99^{\mathrm{a}} \pm 0.68$ & $12.49^{\mathrm{a}} \pm 1.82$ & $21.58^{\mathrm{b}} \pm 4.92$ & $44.28^{\mathrm{c}} \pm 11.95$ & $20.63 \pm 2.30$ \\
\hline Asparagine & $4.99^{\mathrm{a}} \pm 0.19$ & $5.71^{\mathrm{a}} \pm 0.72$ & $24.18^{\mathrm{b}} \pm 4.64$ & $39.22^{\mathrm{c}} \pm 7.78$ & $79.11 \pm 9.79$ \\
\hline Glycine & $16.24^{\mathrm{a}} \pm 1.18$ & $12.68^{\mathrm{a}} \pm 2.33$ & $14.70^{\mathrm{a}} \pm 3.71$ & $29.32^{\mathrm{b}} \pm 9.45$ & $10.69 \pm 1.41$ \\
\hline
\end{tabular}




\begin{tabular}{lrrrrr} 
Glutamine & $102.94^{\mathrm{a}} \pm 5.97$ & $56.57^{\mathrm{a}} \pm 13.35$ & $51.73^{\mathrm{a}} \pm 4.53$ & $49.09^{\mathrm{b}} \pm 11.07$ & $52.04 \pm 6.37$ \\
Alanine & $60.26^{\mathrm{a}} \pm 4.51$ & $61.09^{\mathrm{a}} \pm 10.10$ & $67.57^{\mathrm{a}} \pm 8.73$ & $133.17^{\mathrm{b}} \pm 18.90$ & $38.12 \pm 4.61$ \\
Arginine & $17.71^{\mathrm{a}} \pm 1.29$ & $22.32^{\mathrm{a}} \pm 1.58$ & $66.16^{\mathrm{b}} \pm 14.56$ & $109.22^{\mathrm{c}} \pm 27.55$ & $288.43 \pm 41.91$ \\
Proline & $7.69^{\mathrm{a}} \pm 0.69$ & $11.94^{\mathrm{a}} \pm 2.70$ & $58.57^{\mathrm{b}} \pm 9.95$ & $151.00^{\mathrm{c}} \pm 31.31$ & $171.42 \pm 20.11$ \\
Tyrosine & $12.14^{\mathrm{a}} \pm 2.67$ & $23.97^{\mathrm{b}} \pm 3.12$ & $32.46^{\mathrm{c}} \pm 5.41$ & $59.60^{\mathrm{d}} \pm 4.94$ & $26.41 \pm 3.19$ \\
Ornitine & $2.42^{\mathrm{a}} \pm 0.50$ & $2.53^{\mathrm{a}} \pm 0.54$ & $4.25^{\mathrm{a}} \pm 3.64$ & $14.27^{\mathrm{a}} \pm 16.40$ & $2.11 \pm 0.36$ \\
\hline Other FAA & & & & \\
$\beta$-Alanine & $1.34^{\mathrm{a}} \pm 0.20$ & $1.76^{\mathrm{a}} \pm 0.44$ & $1.83^{\mathrm{a}} \pm 0.57$ & $2.54^{\mathrm{b}} \pm 0.49$ & $2.03 \pm 0.34$ \\
Taurine & $31.04^{\mathrm{a}} \pm 7.56$ & $29.89^{\mathrm{a}} \pm 5.38$ & $22.60^{\mathrm{a}} \pm 7.41$ & $25.89^{\mathrm{a}} \pm 8.35$ & $3.26 \pm 0 . .42$ \\
\hline
\end{tabular}

\section{Dipeptides}

\begin{tabular}{lrrrrr} 
Carnosine & $560.41^{\mathrm{ab}} \pm 108.06$ & $662.21^{\mathrm{bc}} \pm 88.95$ & $712.18^{\mathrm{c}} \pm 66.71$ & $459.41^{\mathrm{a}} \pm 99.23$ & - \\
Anserine & $75.41^{\mathrm{a}} \pm 19.39$ & $96.40^{\mathrm{a}} \pm 21.19$ & $106.72^{\mathrm{a}} \pm 20.46$ & $76.41^{\mathrm{a}} \pm 18.89$ & - \\
\hline Total $* *$ & $\mathbf{3 4 7 . 9 8}^{\mathrm{a}} \pm \mathbf{9 . 4 8}$ & $\mathbf{3 7 4 . 8 2}^{\mathrm{a}} \pm \mathbf{3 2 . 7 0}$ & $\mathbf{7 0 2 . 2 7}^{\mathrm{b}} \pm \mathbf{4 8 . 8 4}$ & $\mathbf{1 3 1 9 . 3 8}^{\mathbf{c}} \pm \mathbf{2 0 2 . 0 2}$ & $\mathbf{1 0 0 7 . 8 6} \pm \mathbf{1 3 2 . 1 7}$
\end{tabular}

*Least square means \pm standard deviations.

**Taurine, carnosine and anserine are not included.

${ }^{a-d}$ LS Means with different letters in the same line indicate significant differences $(p<0.05)$. 
Table 2 Bioactivity characterization of çemen paste*

\begin{tabular}{lc}
\hline Bioactive characterization & \\
\hline ACE-I inhibitory activity (\%) & $93.75 \pm 2.422$ \\
DPPH radical scavenging (\%) & $89.00 \pm 0.007$ \\
Reducing power** & $0.88 \pm 0.008$
\end{tabular}

*Least square means \pm standard deviations. Çemen paste concentration in the extract used for bioactivity characterization was $0.25 \mathrm{~g} / \mathrm{mL}$. **Values for ferric-reducing antioxidant power were based on the absorbance values measured at $700 \mathrm{~nm}$. 


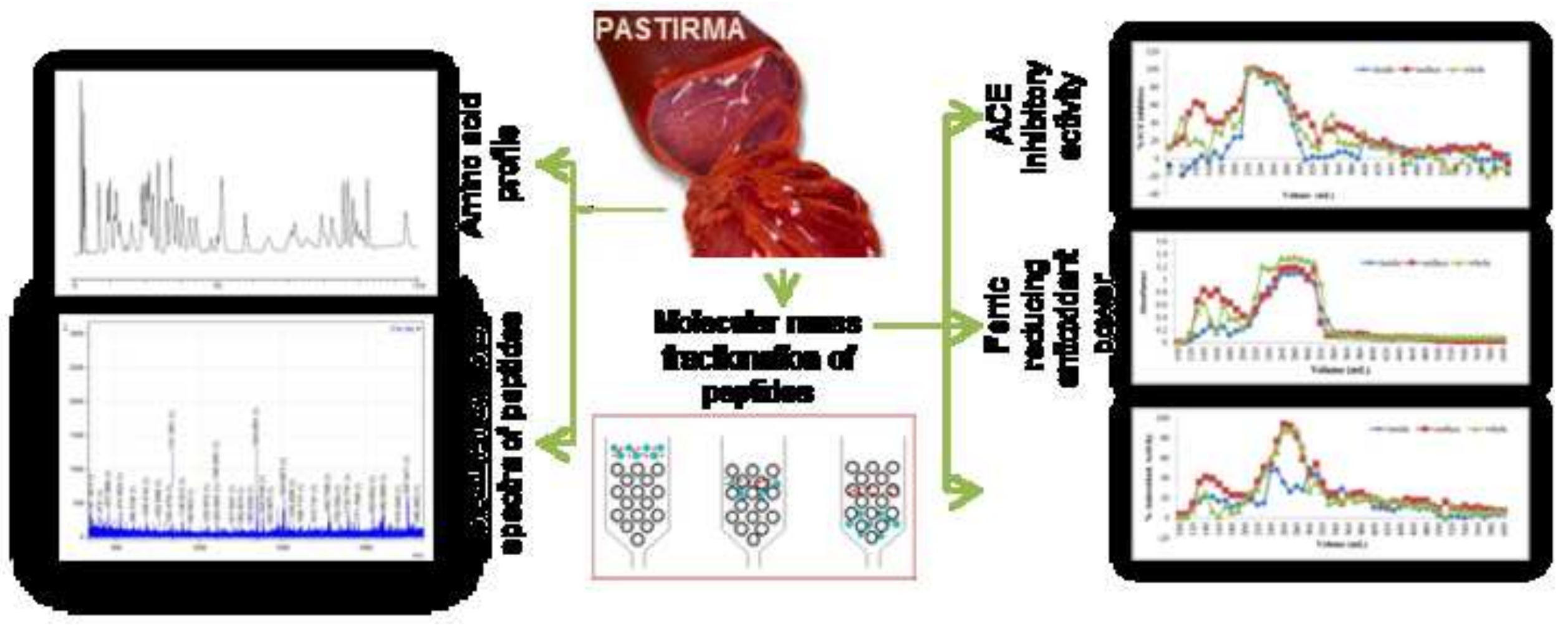

